Boom juridisch

Postbus 85576

2508 CG Den Haag

T (070) 3307033

E info@bju.nl

www.boomjuridisch.nl

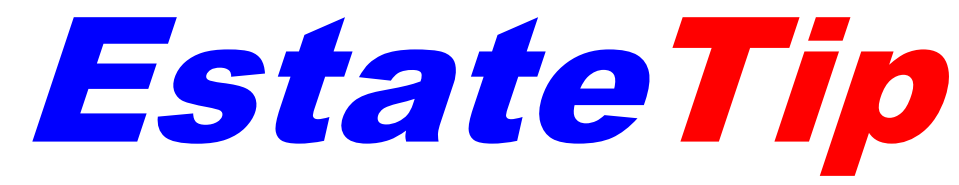

\title{
Estate planning is combineren en individualiseren op de schijf van vijf
}

Het civiele recht en het fiscale recht gaan voor de adviseur hand in hand. De kruisbestuiving tussen de twee rechtsgebieden is groot en van belang voor de estate planning. Hetzelfde geldt voor de combinatie tussen de diverse onderdelen op de schijf van vijf van de estate planning. Maar men dient er ook voor te waken dat niet vergeten wordt ook de afzonderlijke onderdelen op eigen merites, individueel, te toetsen. Is een beding opgezet vanuit civielrechtelijke optiek, bijvoorbeeld een keuze voor bepaalde huwelijkse voorwaarden om schuldeisers buiten de deur te houden, en zijn de gevaren op dat vlak verdwenen, dan is het zaak te bezien of het beding niet beter geschrapt kan worden omdat de eventuele fiscale nadelen nu niet meer opwegen tegen het oorspronkelijk beoogde voordeel op civielrechtelijk vlak. En als een regeling successierechtelijk niet meer interessant is, bijvoorbeeld een verblijvingsbeding in een samenlevingscontract omdat men de partnerstatus heeft (art. 1a Sw jo. art. 11 lid 5 Sw), moet men een dergelijke afspraak niet zonder meer overboord zetten. De afspraak kan immers nog civielrechtelijke waarde hebben.

Om door de bomen het bos te zien, kan deskundig advies van de estate planner niet ontbreken. Waar gehakt wordt, vallen evenwel ook spaanders. Soms gaat het mis en grijpt de rechter in. In deze EstateTip Review aandacht voor twee gevalletjes die toevallig de notaris troffen, maar die ook hadden kunnen zien op estate planners uit andere bloedgroepen.

Uit Hof Amsterdam 25 juni 2019, ECLI:NL:GHAMS:2019:2747, kan de conclusie worden getrokken dat de estate planner altijd het grote geheel, gecombineerd, in beeld moet houden en dat hij of zij zijn of haar opdracht niet te beperkt moet zien. Voor de notaris geldt in ieder geval het volgende:

'6.4. [...] Het is vaste jurisprudentie van het hof dat bij een geschil over de inhoud en/of reikwijdte van de aan de notaris verleende opdracht, het aan de notaris is om zijn stellingen daaromtrent te onderbouwen met een schriftelijke opdrachtbevestiging dan wel gespreksnotities, waaruit een en ander valt af te leiden. In de onderhavige zaak is echter niet gebleken van een door de notaris aan klaagster en haar echtgenoot gezonden opdrachtbevestiging. Ook ontbreken bijvoorbeeld dossieraantekeningen en/of gespreksnotities, waaruit de aan de notaris verstrekte opdracht dan wel hetgeen tijdens de besprekingen met klaagster en haar echtgenoot in 2012 met de notaris is besproken, zou zijn af te leiden. Het is aan de notaris om een opdracht schriftelijk vast te leggen. Thans kan het hof niet vaststellen wat de inhoud en strekking van de opdracht (en besprekingen) is geweest, althans 
dat de aan de notaris door klaagster verleende opdracht inderdaad zo beperkt is geweest als de notaris thans stelt, te weten het opstellen van testamenten uitsluitend met de bedoeling de "koude kant" van de familie uit te sluiten, hetgeen klaagster overigens gemotiveerd heeft betwist. De gevolgen hiervan komen voor risico van de notaris.'

Men kwam voor een testamentje, zo lijkt het. En is het dan aan de notaris om ook de huwelijkse voorwaarden te beoordelen? Er lag een alsof-verrekenbeding, maar dan in een facultatieve variant. Dat is explosief materiaal voor de heffing van erfbelasting, zo weet $u$. Zie Hof Amsterdam 28 juli 2005, EstateTip Review 2005-33 en art. 11 lid 3 SW. Crediteursdreiging was destijds de reden geweest voor deze huwelijkse voorwaarden.

'6.5. [...] Ook in het geval zou zijn komen vast te staan dat klaagster en haar echtgenoot de notaris slechts een beperkte opdracht hadden gegeven, bracht de op de notaris rustende zorgplicht mee dat hij zich voorafgaand aan het passeren van de testamenten had moeten vergewissen van het relevante feitencomplex in deze zaak. [...] De notaris had deze huwelijkse voorwaarden dan ook aan de orde moeten stellen tijdens zijn besprekingen met klaagster en haar echtgenoot en daarbij onder andere moeten nagaan of de feiten en omstandigheden ten tijde van het opmaken van voormelde akte, waaronder de crediteurendreiging, nog steeds aanwezig waren. [...] Het behoorde tot de verantwoordelijkheid van de notaris om eventuele (fiscale) consequenties van het tussen klaagster en haar echtgenoot geldende huwelijksgoederenregime voor de nalatenschap met hen te bespreken en aldus na te (kunnen) gaan wat hun wensen en bedoelingen dienaangaande waren. [...]'

Er had beter gecombineerd moeten worden tussen het civiele en fiscale recht, alsook op de verschillende onderdelen van de schijf van vijf, in casu de huwelijkse voorwaarden en het testament. Zie ook over deze uitspraak G.A. Tuinstra, EstateTip Review 2019-25.

Bij Hof Amsterdam 20 augustus 2019, ECLI:NL:GHAMS:2019:2906, ging het in een tuchtzaak over het prijsgeven van aanspraken ter zake des doods in een contract in ruil voor erfrechtelijke aanspraken in een testament. Doel van de operatie, zo lees ik in de uitspraak, was door eventuele aanpassingen van het bestaande samenlevingscontract en het testament van erflater een goede bescherming te bewerkstelligen. De notaris stelde voor een nieuw testament te maken waarin onder meer de vruchtgebruikregeling uitgebreider en gedetailleerder werd vastgelegd. Daarnaast is voorgesteld om het toedelingsbeding in het samenlevingscontract te ontbinden. Dit had enerzijds te maken met het feit dat het bestaande toedelingsbeding in het samenlevingscontract niet meer in de pas zou lopen met de voorgestelde aanpassingen in het testament. Anderzijds was, aldus de notaris, de oorspronkelijke reden voor het toedelingsbeding komen te vervallen doordat de levensverzekering is beëindigd. Het hof was van oordeel dat, in het licht van de gegeven omstandigheden, het voorstel van de notaris het toebedelingsbeding in het samenlevingscontract te schrappen niet onzorgvuldig is. Dat is mooi, maar toch wordt de notaris, anders dan in eerste instantie (zie EstateTip Review 2019-16), op de vingers getikt. Een punt was onderbelicht gebleven: de herroepelijkheid van uiterste wilsbeschikkingen versus de onherroepelijkheid van het quasi-erfrecht:

'6.2. De notaris heeft [...] een schriftelijke bevestiging gestuurd van hetgeen zij [...] met erflater en klaagster heeft besproken. Ten aanzien van het schrappen van het toedelingsbeding wordt opgemerkt: (...) "het toedelingsbeding wordt ontbonden. Dit betreft een wederkerige afspraak die jullie liever geheel in het testament willen regelen (...)". Het hof is van oordeel dat de notaris niet met deze summiere schriftelijke toelichting had mogen volstaan. De notaris had klaagster uitdrukkelijk, bij voorkeur schriftelijk en op eigen initiatief moeten wijzen op voor klaagster nadelige 
consequenties van het schrappen van het toedelingsbeding. Zij had moeten uitleggen wat het verschil is tussen een tweezijdige overeenkomst als het toedelingsbeding en een eenzijdige rechtshandeling als een legaat. De notaris had klaagster verder moeten informeren dat erflater het keuzelegaat tegen inbreng met uitstel van de opeisbaarheid van het in te brengen bedrag zonder toestemming of medewerking van klaagster zou kunnen herroepen en dat klaagster dan - bij gebreke van het toedelingsbeding en een adequate testamentaire regeling - het risico liep dat zij bij een verdeling van de woning een bedrag ter grootte van de helft van de waarde van de woning zou moeten betalen aan de erfgenamen van erflater. Klaagster betwist de stelling van de notaris dat dit risico aan de orde is gekomen tijdens het gesprek van 13 juni 2017 zodat dit niet is komen vast te staan. Van de notaris had mogen worden verwacht dat zij in haar dossier een aantekening maakt dat dit risico is besproken.'

De combinatie van de twee onderdelen op de schijf van vijf, te weten huwelijkse voorwaarden (en dus ook samenlevingscontract) en de levensverzekering was wellicht niet meer nodig, maar als het contract ter zake des doods geïndividualiseerd was bekeken en nog meer op eigen merites was getoetst dan was de onherroepelijkheid er wellicht in positieve zin uitgesprongen.

Estate planning is derhalve niet alleen combineren, maar ook individualiseren op de schijf van vijf.

Tot volgende week!

Prof. mr. dr. F.W.J.M. Schols

ScholsBurgerhartSchols

\section{Boomjuridisch}

www.scholsburgerhartschols.nl www.boomjuridisch.nl

(C) 2019 Boom juridisch | ScholsBurgerhartSchols

Hoewel de uiterste zorg is besteed aan de inhoud van EstateTip Review aanvaarden de uitgever en de redactie geen aansprakelijkheid voor onvolledigheid of onjuistheid. 